\title{
Survival of the Astute? \\ Horrendous Games and Incautious Players
}

\section{Eman Adel Ahmad Ibrahim Atwa*}

eman.ade126@gmail.com

\begin{abstract}
Within literature, the process of decision-making has long occupied the minds and the works of authors and novelists. Recently, human choices have been influenced by abhorrent challenges - outside the accustomed social and literary interpretations. In this regard, the study suggests a comprehensive understanding of choices by borrowing the ideas of game theory and behavioural economics. In the paper at hand, selected notions of game theory such as cooperative games, noncooperative games, stag-hunt, prisoner's dilemma, incomplete information, and Nash equilibrium - are applied on David Mitchell's Cloud Atlas (2004) and Ben Elton's Blind Faith (2007). To achieve this, the study interprets each novel as a game and its characters as the players who control the game. Along with game theory, it highlights the factors that affect rational choices in the two novels, represented in Richard Thaler's contributions about the constraints of decision-making such as self-control, bounded rationality, and social preferences. In large, by merging the firm rationality of game theory and the bounded rationality of Thaler's theory, the study questions the resilience of human choices under credible threats and social variables in the two novels.
\end{abstract}

Key words: Game Theory, Behavioural Economics, Rationality, Social Preferences, Contemporary Fiction.

* PHD student - Department of English - Faculty of Arts-Fayoum University.

(Survival of the Astute ? ...) Eman Adel Ahmad Ibrahim Atwa 


\section{Introduction}

Game theory is a branch of applied mathematics which "provides general mathematical techniques for analysing situations in which two or more individuals make decisions that will influence one another's welfare" (Myerson 1). Historically, John Von Neumann's and Oskar Morgenstern's book Theory of Games and Economic Behavior in 1944 was the core for game theory as a framework of decision-making. The book proposes an advanced suggestion about economic behaviours in the light of some social inquires. Additionally, by involving some mathematical interpretations, the book examines the complex sides of the economic theories, presenting a number of solutions in this regard. In the world of game theory, any social scenario that gathers two or more persons is known as a "game" and the persons who participate in this scenario are known as "players". In general, players must employ specific techniques which are called "strategies" to attain the profit they aspire to. In turn, those techniques diverse into a scale of probabilities, which controls the "moves" of the players. In all conditions, each player has to determine a strategy for optimization in order to become a winner in the game, thus, "each player must assess the extent to which his or her goals match or clash with the goals of others and decide whether to compete or cooperate with all or some of them" (Davis xiv). For any game, game theorists often postulate two key assumptions: firstly, all players are rational and secondly, those players own the perfect information which enables them to pick out the best among different alternatives. Perfect or complete information "means that there is no private information: the timing, feasible moves and payoffs of the game are all common knowledge" (Gibbons 128). In game theory, the act of rationality is defined as the ability to optimize and attain an optimal utility regardless of distractions and variables. Graham Romp argues that 
rationality means, "that individuals are assumed to act in their own self-interest" and "This presupposes that individuals are able to determine, at least probabilistically, the outcome of their actions ..." (2). In all cases, utility is the prime dominator of the games, therefore, it governs the moves and the strategies of the players. Sometimes, to maximize his outcome, the player must cooperate with the other players - and this is the core of cooperative games. Sometimes, distrust, uncertainty, and social variables oblige the player to optimize independently regardless of the loss of the others in which is called non-cooperative games. Whether the player chooses to cooperate or defect, rationality is crucial to achieve the perfect outcome. To put it simply, game theory rests upon postulating that the individuals can cling to rationality or optimization even under credible threats. This matter leads to problematic hindrances when it is projected on the actual context because humans are neither rational nor can they keep their self-control in situations of risk.

In general, critics and theorists believe that Neumann and Morgenston were the pioneers of game theory. However, economists did not figure out or recognize game theory as a leading theory until 1950 when John Nash discovered the equilibrium in non-cooperative games. Tom Siegfried claims that Nash's "doctoral dissertation ... establishes" him "as the theory's prophet" (56). In his dissertation, Nash presents "the proof of the existence in any game of at least one equilibrium" (Nash 1). If game theory "shows how to determine the strategic necessary to achieve the maximum possible utility" in cooperative games, the equilibrium succeeds in reaching a stable strategy that allows higher utility even in non-cooperative games (Siegfried 28).

In the past, there was a fierce criticism against game theory because of its assumptions about the individuals' absolute rationality. However, in the recent era, game theory has witnessed 
an evolution from a mere game strategy to a platform for many branches such as pragmatics, literature, and social sciences. Mainly, game theory resembles the closest interpretation regarding the mechanism of choice, especially in social dilemmas. James D. Morrow explains, "Social situations involve the interaction of individuals; to study and understand social situations, we need a theory that explains how individuals' decisions are interrelated and how those decisions result in outcomes. Game theory is one such story" (1). In sum, the theory yields its fruits particularly in fiction. Steven Brams maintains, 'Fiction is one of the most fertile grounds for humanistic applications to game theory. Novels, plays, narrative poems ... are all have been subjects to game-theoretic exegesis" (1). Nevertheless, the game-theoretic rationality, standing alone, cannot thoroughly explain the characters' intentions and choices in fiction. Thus, the study weds the rationality of game theory and the bounded rationality of behavioral economics to fiction, aiming at a realistic understanding of human choices.

It is slightly hard to elucidate the ambiguity about behavioral economics in large; however, Sendhil Mullainthan and Richard Thaler describe it as "the combination of psychology and economics that investigates what happen in markets in which some of the agents display human limitations and complications" (ii). Unlike game theory, behavioral economists realize "that our rationality is variable and dependent on the circumstances" (Baddeley 3). Richard Thaler is one of the behavioral economists who supports the model that humanizes choices conversely to the sharp game-theoretic postulates. Thaler admits that the "natural human cognitive limitations and biases" can influence choices (Duignan). In other words, he challenges the economists who ignore the social variables that affect and spoil the rationality of choices, providing a more realistic viewpoint of decision-making. 
Unlike the traditional economists who stick to the model of rationality, Thaler blames "bounded rationality", the loss of "selfcontrol", and "social preferences", for the defection of human choices. As a term, "Bounded rationality suggests that people are neither purely rational neither completely irrational ... that because human beings are limited in how much information they can process ... they are prone to errors ... when they formulate their preferences and choices" (Baumeister and Vohs 106). Thus, "when things get complicated, Humans can start to flounder", hence they lose control over their choices (Thaler 256).

Besides bounded rationality and self-control, Thaler sheds light on the social temptations or preferences, which are beneath the economists' radar. Unlike rational judgments, "social preferences seem to be prone to psychological considerations. They may involve emotions such as empathy, sympathy, care, resentment, guilt, shame, etc" (Lisciandra 2). Theoretically, these preferences do not influence the rationality of humans, but in practice, they play the central role in limiting the knowledge of the players in game theory. As these preferences lack the rational obligation, they sometimes represent a credible threat that forbids attaining profit. In all cases, bounded rationality, self-control, and social preferences overlap in the realm of choices, leading to one and only result: irrational choices.

In essence, game theory and behavioural economics cover more than mere calculative potentials for solving choice conflicts. Their notions present irrefutable explanation of decision-making including its hindrances like norms, beliefs, morals, and social menaces. To this effect, through this paper, a group of game theory tents and strategies such as (prisoner's dilemma, stag-hunt, cooperative games, non-cooperative games, incomplete information, and Nash equilibrium) along with Thaler's 
theory of decision-making will be applied on two novels: David Mitchell's Cloud Atlas and Ben Elton's Blind Faith.

Among all tents, prisoner's dilemma is the very notion akin to social quandaries and choice paradoxes, as it utilizes no math while interpreting decision-making. It mainly centers on the clash between the individual's and the group's benefit. Jan Narveson explains, "In BD there is partial conflict, and decisions can become very complex. Two players with two options each are so related that one player's best outcome is the other's worst, and vice versa" (509). In brief, the prisoner's dilemma game is a tale of two criminals who are arrested for robbery. As the police officers are unable to prove their guilt, this leads the criminals to two alternatives: to confess or not to confess. If both of them decide to confess, each will be detained for five years. If one of them decides to confess and the other decides not to confess, the criminal who does not confess will be detained for ten years and vice versa. If both decide not to confess, both may be detained for one month.

In the game, the optimal strategy obliges both criminals to cooperate - and this requires trust - which depends on the social beliefs and experiences. In other words, cooperation resembles the perfect solution for this dilemma, furthering outcomes for both the individual and the group. Robert Axelrod summarizes:

The distinguishing feature of the Prisoner's Dilemma is that in the short run, neither side can benefit itself with a selfish choice enough to make up for the harm done to it from a selfish choice by the other. Thus, if both cooperate, both do fairly well. But if one defects while the other cooperates, the defecting side gets its highest payoff, and the cooperating side is the sucker 
and gets its lowest payoff. This gives both sides an incentive to defect. The catch is that if both do defect, both do poorly. Therefore the Prisoner's Dilemma embodies the tension between individual rationality (reflected in the incentive of both sides to be selfish) and group rationality (reflected in the higher payoff to both sides for mutual cooperation over mutual defection). (4)

Prisoner's dilemma is not though, a set of moves to choose at a glance. The game is devoted to morals and preferences rather than rational judgment and mutual benefit. Decisions, as well, change due to threats and social pressure. In other words, cooperation may be reckless, and selfishness may be secure. Thus, on one side, the individual chooses according to his beliefs, albeit irrational. The group on the other side imposes its laws on individuals, a fact that makes prisoner's dilemmas cyclic and infinite.

Notably, social dilemmas have catalyzed the prisoner's dilemma so do other selected games and strategies. Stag-hunt game, for instance, "is a prototype of the social contract" (Skyrms 31). Like prisoner's dilemma, stag-hunt is a module for choice under incomplete information and threats. However, stag-hunt occurs when the personal safety clashes with the group's benefit as the individual chooses "between a safe option that pays a fixed but moderate payoff and a risky one that pays more if the other player also goes for the risky option" (Bolton et al. 411). In the game, "No individual is strong enough to subdue a stag by himself, but it takes only one hunter to catch a hare", therefore, "mutual cooperation takes on the highest value for each player" (Fang et al. 451). Indeed, it is trust that activates cooperation through the game. Trust, 
though, is not spontaneously chosen regarding human behaviours. It is always inclined to social preferences, information, and threats. Richard Thaler and Cass Sunstein put it, "social influences have caused people to have false or biased beliefs", wreaking a choice defection (58).

In the light of the above overview, this paper treats Cloud Atlas and Blind Faith's incidents according to the realm of the society/individual games. It also argues how decision-making, albeit unquestionable, can become moot under social influence. By constructing a game-theoretic scheme for each novel, the paper examines the characters' choices regarding the society/individual game. Similarly, it traces the rational/irrational responses against social impulses and lack of information, revealing the win-lose outcome.

\section{Cloud Atlas: Chronic Choices}

Cloud Atlas is a post-apocalyptic novel that consists of six interconnected narratives that are listed as follows: 'The pacific journal of Adam Ewing', 'Letters from Zedelghem', 'Half-Lives: The First Luisa Rey Mystery', 'The Ghastly Ordeal of Timothy Cavendish', 'An Orison of Sonmi-451', and 'Sloosha's Crossin' and Ev'rythin'. The novel concentrates on multiple oppressive human behaviours in the scope of historical, cultural, political, and social elements during eras from 1818 till the unknown future.

In Cloud Atlas, Mitchell provides us with an unorthodox perspective of decision-making by highlighting six interlinked experiences, six overlapping options, and six identical behaviours. Notably, the choice of each protagonist in every story clings directly/indirectly to the decisions of other protagonists in the remained stories. 
Furthermore, each decision flips between two alternatives. For instance, enslavement is a reaction to nobility, plagiarism defects originality, and authority destroys humanity. Hence, if we consider Cloud Atlas's decisions a cast stone, then all choices are equal. Thus, choices seem to be connected while reading the whole narrative despite variables of time, culture, threats, and baits. We, though, can judge each decision apart from the structure of the novel.

So far, the novel situates a detailed history of decision-making according to the moves of six characters: Adam Ewing, Robert Frobisher, Luisa Rey, Timothy Canvedish, Sonmi-451 and Zachry. The first narrative entitled 'The Pacific Journal of Adam Ewing' occurred in 1850 when Ewing - a lost American notary from San Francisco - stopped by the harbor to repair his ship in the Chatham Islands. There, he witnessed the torturing of a slave called Autua by a Maori supervisor. To this misery, Ewing felt disappointment and discontent. Soon after, Ewing ascended the Conical Tor hill where he saw a group of faces engraved on the trees. This horrific scene frightened Ewing to the extent that he became bedridden on the ship. Thus, he asked his only friend, Dr. Henry Goose, to examine his serious injuries that were caused by his rush while he was escaping from the hill. During the examination, Dr. Goose informed Ewing about his chronic disease, recommending a full treatment course on the ship.

Later, Autua proved himself as a first-class seaman. Yet, slaves were not allowed to be seamen. Ewing, as a white man, used his authority to persuade the captain of Autua's skills. Therefore, Autua led the journey to Hawaii. In the second part of the narrative, Ewing visited the island 
of Raiatea, where he witnessed the missionaries abusing a large number of people. As his illness became worst, Ewing returned to the ship. There, he realized that Dr. Goose intended to kill him by poison. Fortunately, Autua rescued Ewing from death and theft as Dr. Goose aimed at stealing Ewing's jewels. Therefore, Ewing decided to join the abolitionist movement to end slavery. Finally, Ewing was able to recover. Then, he wrote an article, clarifying that history was presented by the consequences of awful and upright acts that were encouraged by human choices and beliefs. This article called for an equal world, and in turn, it converted into the Pacific Journal of Adam Ewing, which inspired the rest of the characters in the different eras.

In the second narrative entitled 'Letters from Zedelghem', the shadow of Ewing's journal was revealed as a rare book brought by Robert Frobisher. Frobisher was a young English musician, who used to be a rich man, and whose family was deep in debts. Therefore, he traveled to Zedelghem in 1931 to escape from the debt collectors. In Zedelghem, he searched for the composer Vyvyan Ayrs then he became his student. As Ayrs was an aged man, he allowed Frobisher to be his amanuensis. In this way, Frobisher learnt how to compose melodies. Later, Frobisher composed a basic melody that Ayrs suggested to him, naming it The Death of the Bird. After that, Frobisher composed his own melody Cloud Atlas Sextet then he shared it with Ayrs. However, Ayrs intended to plagiarize Frobisher's melodies, demanding full concerts. Otherwise, he would accuse Frobisher of raping Jocasta, Ayrs's wife. Ayrs was aware that Frobisher had illegitimate relationship with Jocasta, but he ignored this infidelity. In the first 
place, Ayrs wanted to restore his popularity with the help of Frobisher's melodies, and this was the real reason why he manipulated Frobisher. Realizing the unavoidable results of his behaviours, Frobisher wrote a letter to his friend Rufus Sixsmith, including his sextet and the pacific journal of Ewing. Then, he committed suicide in a hotel.

In the third narrative entitled 'Half-Lives: The First Luisa Rey Mystery', Sixsmith met Luisa Rey in California, 1975. Rey was a young journalist whose father used to work as a police officer then a war correspondent. Rey was a specialist in exposing the corruption of the corporates. In their meeting, Rey and Sixsmith shared their worry about the nuclear HYDRA power plant. Sixsmith, as a scientist, listed the dangerous effects of activating this project. At the hotel's room, Sixsmith handed Rey the letters of Frobisher. After that, she was informed that Sixsmith died in a plane crash. Luckily, Sixsmith left a report about the corruption of the HYDRA nuclear plant. The narrative ended when an assassin was chasing Rey because of this report. Yet, Joe Napier, a friend of Rey's father, saved her. She reported the corrupted businessmen of HYDRA to the public. Then, she has received the remained letters of Frobisher, including the sextet and the journal of Ewing.

The fourth narrative entitled 'The Ghastly Ordeal of Timothy Cavendish' is about Timothy Cavendish - a vanity press publisher in Britain - who was followed by the brothers of a gangster whose book became a bestseller after the murder of a critic. To this effect, Cavendish hided in a nursing home where he briefly read a manuscript named 'Half-Lives: The First Luisa Rey Mystery'. However, the plot did not impress him. Soon after, he successfully fled from the nursing home with his colleagues. At the end of 
the narrative, Cavendish was able to return to his office because his secretary blackmailed the gangsters by showing them a video of their office's break-in. Then, he obtained the full version of Rey's manuscript and decided to publish it.

The fifth narrative entitled 'An Orison of Sonmi451', revolved around a dystopian Korean future. The first scene occurred in a record room where the archivist is recording the confession of Sonmi-451 before execution. Sonmi-451 was a genetic experiment that worked as a waitress in Papa song's restaurant. Sonmi and other genetic experiments' intelligence were controlled by the blueblood society, using a special kind of food, known as 'Soap'. In her confession, Sonmi admitted that some faculty researchers assisted her to understand self-awareness after she left the restaurant. In addition, she watched the movie of The Ghastly Ordeal of Timothy Cavendish that summarized the universal disasters in the light of human technological ability, which caused the clash between different communities and ruined the whole world except the Nea So Copros. She revealed her relationship with Im Hae-Joo, who was one of the rebels against the genetic slavery and who used to be her guider. At the rebels' tent, she witnessed what happened to her colleagues of genetic experiments after retirement. The blueblood society butchered them, converting them into Soap to feed the other fabricants. Thus, Sonmi decided to join the abolitionists of the 'unfortunate blueblood'. Aiming at an equal society, Sonmi wrote declarations for the revolutionists, relying upon the ideas of Ewing about oppression. During the public execution, she was pleased 
that her rebellion would inspire people to get rid of enslavement.

The sixth narrative entitled 'Sloosha's Crossin' and Ev'rythin' After' is about Zachry, who lived in dystopian Hawaii where the black slaves of the Kona tribe torture and murder the white race of the valley folk tribe. The valley folk tribe used to worship a goddess called Sonmi-451. Zachry's family was killed except for him and his sister. Therefore, he was a good victim to moral doubts and selfremorse. One day, Meronym - a woman of the Prescients (a developed sophisticated tribe) - visited his village to investigate the valley folk's life style. She offered help for Zachry; however, and according to his preferences of human deception, he did not trust her. Meronym attempted to persuade Zachry that sonmi-451 was not a goddess as the valley folk thought. Thus, he claimed that Meronym's lies were nothing but devilish whispers, intending to kill her. Hence, he sneaked into her room. There, he found an orison of an egg shape with a holographic video, broadcasting the picture of Sonmi's speech in the public execution. Slowly, Zachry was able to believe Meronym and he became certain that Sonmi was just a fabricant. Then, in order to save his tribe, he guided her to the Mauna Kea Observatories. While Zachry and Meronym were returning to his tribe, they found that the folk valley people were attacked until death. That is why Meronym offered escaping the village. Then, Meronym told Zachry about the real story of Sonmi-451. The novel ended with Zachry narration to his children about what happened to the folk valley while one of his children was holding the Sonmi's orison. 


\section{Cloud Atlas: Several Variables and Repetitive Choices}

As a decision-making map, Cloud Atlas's atmosphere fits the win-lose conditions that establish the mechanism of game theory. Approximately, the novel "is structured like a Russian doll, with the reader progressing forward through a series of interrupted narratives, and then, after a pivotal middle section, methodically working back through the narrative plots in reverse order" ( $\mathrm{Ng} \mathrm{107).}$ Thus, one can trace the variable phases of each game such as the incomplete/complete information, the credible/noncredible threats, and the probability of cooperation/noncooperation. This section explains how the outcome of each narrative depends on the next narrative's choices and how each preference empowers the first irrational choice of the Maori people. In addition, it discusses the reason why the characters could not achieve profit since Ewing's time despite owning the advanced strategies that enables them to win the game effortlessly.

\subsection{Choice No. One: Nobility or Enslavement}

In the first narrative, Adam Ewing's choice sways between rationality and sentimentality. Obviously, sympathy regulates his moves. For example, it is the flogging of Autua that urges Ewing to interfere rather than his sense of responsibility towards the underdogs or his belief that all people are equal. Ewing's aim is to end Autua's suffering; hence, Autua can become a seaman. However, Ewing does not thoroughly think about the consequences of enslavement on him and his tribe. Ewing's behaviour can be explained in the essence of prisoner's dilemma games, whereby he is not able to predict if Autua will be the one who serves his savior or the savage who 
kills his master. It seems like a game of incomplete information and credible threat that stems from the reputation, which the white race forges about the black slaves in the novel. Ewing's hesitance is traced in his narration as he does not recognize Autua's name until the last part of his story. He pities Autua; however, he calls him the savage. He mentions, "The beaten savage raised his slumped head found my eye \& shone me a look of uncanny, amicable knowing!" (6). For noble men, in the novel, Autua and other slaves are savages who deserve extermination. Thus, the dilemma of distrust, which is imposed by the conflicts of racism, destroys the rational necessity that calls for cooperation in the game.

In the first narrative and other narratives that form the whole novel of Cloud Atlas, choices and characters do not reflect a mere transient history for the other decisions and persons in the next era. Instead, each protagonist has a minor shadow, which acts with the same motif, albeit in a different technique. For instance, Autua's character stands for the racist Ewing who allows the Maori's oppression towards the Negros. Similarly, Dr. Goose's management to deceive Ewing equals the tyranny of the Maori who exploits the talents and the souls of the black slaves. Lynda $\mathrm{Ng}$ illustrates, 'The Maori's subjugation of the Moriori is mirrored, on an individual level, by shipmate Henry Goose's attempt to murder Adam Ewing and steal his possessions during the journey to America" (111). In many ways, Autua's weakness, as a black man, so do Ewing's apathy, as a white man, contribute to the savageness of both the Maori and the white race. Also, Goose's greed and the Maori's stubbornness impede by achieving utility for the conflicting tribes. 
With regard to the previous, the games become frequent as well. To put it simply, the prisoner's dilemma game between Autua and Ewing is similar to the game between the Maori and the Moriori and both games naturally pave the way to the game between Dr. Goose and Ewing. Conversely, Ewing trusts Dr. Goose; therefore, it is much easier for him to cooperate. Nevertheless, the perfect information that Ewing claims that he owns about Goose stems only from his bias towards the white race. In game theory, leaning on common backgrounds of judgment does not maximize the outcome of the game of any type. Ewing consults no one about his illness except Goose, a decision that is taken for sentimental consideration rather than rational judgment. Hence, he loses the game.

On the other side, he succeeds in achieving a rational equilibrium in a non-cooperative game with Autua. Autua resorts to Ewing in order to avoid oppression by becoming a seaman on the ship. Many potentials arise regarding Autua's decision such as why should Ewing cooperate? What will happen to Autua if Ewing decides not to cooperate? On the other side, Ewing questions the sincerity of this slave. Yet, both of them choose the utilities, forming a successful alliance. Autua wants to get rid of slavery and forces people to respect his skills as a seaman. He wants to show noblemen that Negros are people of talent rather than demagogy. Ewing wishes to expedite his journey to meet his wife and treat his illness. His choice depends on perfect information about Autua's skills. Therefore, we consider Autua and Ewing stag hunters according to game theory as both of them choose the same rational choice of mutual benefit in a noncooperative game. Once again, Autua proves his rationality 
when he saves Ewing from Dr. Goose's attempt of murder. Autua is fully aware that Ewing is a man of authority and ability to change the society of slavery. Autua's ability to predict the moves of Ewing is, after all, admirable. To this effect, Ewing decides to support the abolitionists. Moreover, he writes the pacific Journal about beliefs that can change the society. From a game-theoretic perspective, Ewing's decision to document this era by spreading ideas about equality and humanity is intentionally rational; however, it is practically sentimental.

\subsection{Preference No. One: Nobility}

The social preference that governs the first narrative is nobility and slavery starting with the Morori who allow trafficking in 1850 to protect the white race from - the soclaimed - the black savages. One of them justifies his oppressive attitude to Ewing, "Imagine a bleeding in sharkinfested shallows. What to do - stay out of the water or try to stay the jaws of the sharks? Such was out choice ... what moral to draw?" (15). This racist declaration does not stem from rational judgments or social necessity towards enslaving Autua and his tribe. Rather, it is greed that motivates the missionaries, supplanting the original theory of choice. Another example is Dr. Goose's choice to poison and steal his only friend, an act that is repugnant to noble men from a rational and social view. On the other side, Autua joins the rebels to soothe the soul of his fugitive relative, preferring to revolt under sentimental sanction instead of strategic motivator to break the social preference. Moreover, his decision to show his skills or to gather for rebellion portrays a limited ambition of escaping slavery rather than a rational desire to obtain the right of equality. In a conversation, Ewing asks him if he is 
satisfied with his position as a seaman, he confirms, "Better'n slaving for Kupaka, Missa Ewing" (37).

\subsection{Choice No. Two: Originality or Plagiarism}

The second narrative is full of anti-sensible choices and faulty calculations; however, it witnesses one equilibrium in a non-cooperative game between Ayrs and his wife. The game begins when Robert Frobisher decides to travel to Belgium in search for the once great musical genius Ayrs. He confesses, "My daydream had me travelling to Belgieum, persuading Vyvyan Ayrs he needed to employ me as an amanuensis, accepting his offer to torture me, shooting through the musical firmaruent, winning fame and fortunate commensurate to my gifts" (45). Apparently, Frobisher's decision is influenced by Ayrs's fame, rather than detailed information about whether the Frobisher/Ayrs alliance will achieve what Frobisher dreams of. According to the rules of game theory, each human behaviour is a game as long as there are two players with mutual needs. Frobisher wants to become an admirable musician like Ayrs. In addition, he wants to get rid of money collectors who pursue him and his family. As for Ayrs, he wishes to restore his lost glory. The deal is that Ayrs teaches Frobisher how to compose melodies while Frobisher helps him at home, beginning a stag-hunt game. Alliance indeed attains higher utility for both players. Thus, Ayrs and Frobisher cooperate regardless of conflicts of distrust, maximizing their benefits in a win-win strategy. Frobisher maintains, "A work routine is developing, Ayrs and $I$ are in the music room by nine o'clock every morning ... I sat on the piano, Ayrs on the divan ... I hum, sing or play ... and Ayrs modifies the score" (59). Yet, the factor of sentimentality interferes with the game. Unfortunately, 
Frobisher gets involved in an affair with Ayrs's wife. On the other side, Ayrs is obsessed with Frobisher's masterpiece, intending to copy it. Thus, "The ruthless Vyvyan Ayrs uses an affair his wife entertains with" Frobisher "to pressure the insecure young man and exploit his musical talent" (Walther 11-12). The non-cooperative game between Ayrs and his wife becomes vital when they use a credible threat to sue Frobisher. Both do not cooperate to destroy Frobisher's life. It is a single sided decision whereby Ayrs prefers his personal interest, ignoring his wife's infidelity. Jocasta, Ayrs's wife, also prefers to manipulate Frobisher for her own pleasure. These selfish choices achieve the best outcome for Ayrs and Jocasta, causing a fatal defect for the sentimental Frobisher. Out of fear and frustration, Frobisher decides to commit suicide, sending a copy from his masterpiece, Cloud Atlas Sextet, to his friend. In doing so, Frobisher makes his first and last rational choice in the novel, borrowing the style of Ewing Pacific journal through documenting the sextet in his letters to Sixsmith who, in turn, spreads the melody to the era of Lusia Rey.

\subsection{Preference No. Two: Plagiarism}

Interestingly, neither behavioural economists nor Thaler himself were able to understand why people may fail to choose strategically or why they repeat the same faulty scheme of choice in recycled situations. Along with them, the reader disapproves of Frobisher's insistence to repeat his irrational moves in his game with Ayrs. In the beginning, Frobisher's rationality is affected by his limited information about Ayrs. Thus, his bounded rationality does not enable him to seek an optimal outcome. However, although Frobisher regrets his relationship with Jocasta 
which, distracts him from his personal dream to become a musician, he traps himself in another relationship with her daughter, Eva. In doing so, Frobisher uses his bounded rationality for the second time, attaining a new loss. He already burdens himself by the possibility that Ayrs may be informed about his action. Therefore, why does Frobisher impose a new barrier?

Obviously, Frobisher does not weigh his decisions due to facts. He is influenced by the social preference that glorifies famous people that is why he chooses Ayrs in specific. However, if Ayrs is genius according to public judgment, this does not make him great per se. If he allows Frobisher to stay and learn, this does not make him generous. All these elements are considered uncertain information and do not reflect the actual behaviour of humans. Ayrs himself is aware that crowds will support him against Frobisher due to the social preference of fame. He explains, 'They don't pay money for Vyvyan Ayrs only to get Robert Frobisher V.A. ... Why would such an artist possibly need to 'plagiarize' anything from a copyist who may I remind him was unable to obtain even a bachelor's degree for himself from a college" (455). In the reputation game, the society will support Ayrs because, after all, "Reputation is king of the public sphere" and "It is dethroned by public acts" (456). Thus, according to preference, people cannot accuse Ayrs of plagiarism, albeit it is true. They rather prefer to blame a nameless musician like Frobisher. To this effect, Frobisher sadly realizes the consequences of his sentimental preference, admitting his loss.

\subsection{Choice No. Three: Authority or Revolution}


This third narrative does not involve many choices. It concentrates on two main behaviours: Sixsmith's decision to hand his report about the nuclear plant to Luisa and Luisa's insistence on uncovering the HYDRA's corruption. The game between Luisa and Sixsmith is cooperative despite the incomplete information as both of them meet for the first time. Nevertheless, they obtained higher utility, achieving a great equilibrium of rationality. Due to this cooperation, Sixsmith is able to spread the melodies of Frobisher, represented in Cloud Atlas's Sextet. As for Luisa, she obtains an evidence for her interrogation against the HYDRA Nuclear. At the end, she uncovers the corruption of the HYDRA to the whole community. Her decision serves as a deterrent to the corrupters in her era, but corruption remains on the list of the human choices in the next era.

\subsection{Preference No. Three: Revolution}

In 'Half Lives: 'Half-Lives: The First Luisa Rey Mystery', the social preference of anger is the super motivator for Luisa's actions. She does not rely upon strategic principles that oppose corruption, considering it a game of loss. She rather follows the steps of her father who shows unusual bravery in fighting corrupted people. She explains, 'Lester Rey was one of only four or five journalists who grasped the war from the Asian perspective. I'm fascinated to hear how a policeman became of the best correspondents of his generation" (92). Yet, her father's choice is also colored by his desire of hero ship with no reference to rationality. Thus, in the lens of behavioral economics, Rey is devoted to her social preferences more than her rational duty as an anticorruption journalist. The sentimental resentment prevents 
Rey from attaining an optimal utility on the long-term. As the key point of decision-making is the successful and perfect outcome, neither Rey nor her father were able to obtain a perfect pay-off.

\subsection{Choice No. Five: Revolution or Authority}

In the fifth narrative, Sonmi-451 is a fabricant that is designed by the blueblood society, with limited intelligence and zero sentiments. The game begins when a group of researchers decides to polish its intelligence by developing speech patterns. Later, Sonmi discovers that they are members in the union of 'unfortunate blueblood' whose gathering is established for destroying slavery and the blueblood society. They choose Sonmi to lead the revolution, giving her a real soul. In addition, they set up Im Hae-Joo as her guarder. The cooperative game between Sonmi and the union is unfair because they provide Sonmi with imperfect information about their aims. Moreover, they fuel her thoughts with doubt and resentment. They let her see what happens to fabricants, which are butchered and recycled into Soap, a credible threat that affects her rationality. After all, this union selects a fabricant to become a figure of revolt. Then, why do not they develop the other fabricants' thinking instead? Their choice is not strategic because what motivates them is to pull the rug out from under the powerful bluebloods, becoming the new bluebloods.

\subsection{Preference No. Five: Authority}

At this stage, the reader may ask, how does Sonmi's get involved in revolution despite the fact that she lacks sentimental judgment? The answer is that the union creates a preference for Sonmi to follow. They modify Sonmi's behaviour, planting a sentimental influence to affect its 
rational choice. In the novel, her sentimental bias is traced in her speech with the archivist. She states, "To enslave an individual troubles your consciousness. Archivist, but to enslave a clone is no more troubling than owning the latest six-wheeler ford, ethically. Because you cannot discern our differences, you believe we have none" (187). Neatly, the union deceives Sonmi, assuming that the blueblood society is chasing her. That is why she follows Im Hae-Joo regardless of the consequences. She explains, "Hae Joo told me I could trust him or to be dead in a matter of minutes ... I did not know. I was not sure. My decision was based on character. I could only hope time would prove it well founded" (313). Furthermore, they present to her a stimulation of the butchered fabricants as she confesses, "I watched the clusters of embryo fabricants suspended in uterine gel; I was witnessing my own origin, remember. Some slept, some sucked thumbs, some scurried a band or foot as if digging or running" (323). Besides these preferences, Ewing's Journal plays the last role in convincing Sonmi to be a fugitive. The journal suggests the common action of people who witness oppression and how they should behave. Sonmi concludes that the 'fortunate blueblood society' is an epitome of the Maori, Dr. Goose, Ayrs and the Cavendish's gangsters. Thus, Sonmi-451 decides to revolt, yet, her decision relies upon bounded rationality, which suffices to Ewing's journal. Thus, she enables the 'unfortunate bluebloods' to become the new blueblood society, but she does not cast aside the ideas of enslavement.

\subsection{Choice No. Six: Enslavement or Nobility}

The six narrative summarizes the outcome of the previous cooperative, non-cooperative, stag-hunt, and 
prisoner's dilemma games. It discusses the results of incomplete information and credible threats on humanity. This era is the product of irrational choices of the characters all over the centuries. In a way or another, "Zachry's narrative bears the cumulative weight of all the narratives that came before", yet, it is the era where the protagonists finally own a history about decision-making (Mezey 19). Thus, according to perfect information, the Kona tribe is supposed to act rationally after they learn about the consequences of oppression from the first Hawaii's narrative where the white nobles used to murder the black slaves in 1850. However, Zachry's era is just another traditional game that is inspired by games between the Maori and the Moriori.

Unlike the original game, the slaves rule and direct the moves of the white people. Despite the fact that all the players realize that equality optimizes the utility for the Kona and Zachry's tribe, non-cooperation controls the game, converting it into a stag-hunt game. Because safety is a matter of life or death for Zachry and his family, they choose their own interests. They, though, achieve no profit because they were all killed except for Zachry. Because of these circumstances, Zachary is not able to trust Meronym in a prisoner's dilemma game. Thus, their cooperation has been delayed, failing to rescue his tribe. In this game, Zachry's thoughts exercise a credible threat that adheres to the concepts of Sonmi as a goddess. Thus, he considers that cooperation with Meronym, albeit rational is prohibited per se. Yet, by getting rid of the non-credible ideas that the society sets up without authentic evidences, Zachry decides to cooperate with Meronym at the end. This act "underlines that every human being represents a potential agent of 
change", even "subaltern individuals who lack higher education and do not belong to a sophisticated culture" can "co-determine the fate of humanity" (Walther 49). After all, no matter what is the background of the players as long as they paly rationally and strategically. Thus, Zachry with his limited knowledge and Meronym with her insight are able to attain an equilibrium. On one side, they maximize their profits and success to survive. On the other side, they offer us a glimmer of hope that rational choices still can control the human behaviours in the chaotic worlds.

\subsection{Preference No. Six: Enslavement}

In this narrative, the social preference of vulgarity and civilization shows up again. Also, there is a reflection of Sonmi's as a goddess which can be considered a social preference as well. Shockingly, Zachary does not believe Meronym's assumption that Sonmi is fabricant. Even when Meronym shows Zachry a holographic video of Sonmi, proving that she is not a goddess but an icon of revolution, still Zachry is devoted to the social legacy. The cooperation between Meronym and Zachry seems impossible because she "shows a more mindful and understanding demeanor than Zachry, who has to fight with personal issues and initially shows hostile behavior, the uneducated Shephard functions as protagonist of the story" (Walther 77). Yet, it is the social preference that glorifies Sonmi, which deepens Zachry's bounded rationality rather than his ignorance. Once he gets rid of this constraint, he regains his rationality and obtains the desired outcome.

\section{Blind Faith: Garbled Choices}

Ben Elton's Blind Faith explores the position of choice under three threats: global warming, 'excessive sharing', and the death of many children due to the measles 
epidemic. Generally, Elton divides the sequence of incidents into two conditions: before and after the flood. In this way, he converts decision-making from a human necessity into a peripheral item, even an unlawful item. The era before the flood is not mentioned thoroughly in the novel. Protagonist as well as characters, though, believe that flood is the reason, which seized their will. Such natural catastrophe, they claim, is a forced act decided out of their own accord, then why they are obliged to bear the brunt of it. After the flood, the afflicted society of Blind Faith is supposed to grasp at every opportunity to regain authority over its choice. However, the community limits the capacity of decision-making by establishing 'the Temple'. The Temple is a social gathering that consists of confessors and priests who are supposed to guide the community in the after flood era. Unlike the tolerance/rejection privileges that accompany natural calamities, the right to choose is not affordable by 'the Temple'. According to the Temple's rules, privacy is infidelity. Therefore, people have to publish online every tiny detail about their lives involving sexual activities, visual eating, moments of birth, ceremonies, and funerals. In addition, people have to decline science, knowledge, and reason. Otherwise, they will be accused of perversity and disbelief, facing a possibility of execution. The Temple marshals three reasons why 'sharing' is the core of faith: a) it is a swerve to keep secrets because only perverts stick to privacy, b) people tend to cover up their actions due to embarrassment or guilt, and c) people associate their suffering with God by broadcasting their anguish in their blogs. The blogs are monitored through a unit called 'Fizzy Coffs" to guarantee that people keep their faith by 'sharing'. 
In Fizzy Coffs, the mission of the novel's protagonist Trafford Sewell is reviewing people's 'online content' and storing data about the population. As a civil servant, Trafford has to record the gory details that people post in their blogs. The novel begins when Trafford questions the purpose of collecting the community's data while everything is already published online. In other words, he finds his job meaningless while people expose everything about themselves from their bodies to their sensitive videos of birth operations. To this effect, Trafford doubts the purpose of 'sharing', questioning why privacy is illegal matter per se. Urged by "the pleasure to have a secret" while "people were itching to tell their stories", Trafford delays posting online videos of his daughter, Caitlin (12). Unfortunately, confessor Bailey notices Trafford's suspicious behaviour, asking Trafford "Why did" he "not Tube a birthing video?" (29) Trafford "knew the answer but he could never say it. He could not possibly confess that his decision ... had been the result of a strange force deep within him which desired a moment of privacy" (29). Thus, Trafford alleges forgetting for not sharing the videos of his daughter's birth, assuring, "nobody would be interested" (30). In this way, Trafford endorses privacy and similarly choice. Notably, by rejecting 'sharing', Trafford realizes his ability to act as a decision-maker in the novel.

So far, acknowledging the power of choice is a sequential process, precisely; contagious because owning privacy is not Trafford's exclusive decision. Firstly, he decides to veil his recognition of privacy. Secondly, he never capitulates to his wife's demands about sharing their sexual videos online. His wife Chantorria, in turn, expresses her worries of social disapproving which obliges 
the population to share their sexual pleasure with the community. In many ways, Chantorria's fears borders on the absurd. However, what seems to be a faulty, even irrational fear against Trafford's logic is, after all, a choice; that the novel's community lacks the prosperity of apprehension. Mainly, the crowds share without editing their videos and none of the population is interested in browsing other blogs. Even terrorists who post information about their terror are not confined. The Temple is a society where people share because 'sharing' becomes an axiom rather than a protection against execution. Trafford states, "In fact the vast majority of the population (including most potential terrorists and random killers) publish every possible detail about their lives on their Face Space pages" (19). For the Temple, 'sharing' is natural like a scientific fact, and sharing the same content without selecting a distinguishable subject for your blog is instinctual as well. Therefore, any act apart from that 'blind sharing' is considered to be a choice, whether it is rational like Trafford's embrace of privacy or silly like Chantorria's fear about her blog's content.

Since 'public sharing' no longer attracts Trafford, he cautiously traces people who may have secrets among the crowds. That is, when he discovers Sandra Dee's blog - a colleague who posts fake videos about her life copied from other blogs. The work of Sandra is superbly original, as she shares almost nothing about herself, retaining her privacy and choice against the Temple's rules. By "playing the simplest trick", Sandra breaks the Temple's rules by picking videos of girls whose bodies look like hers, and then shares their videos as hers. Also, she modifies videos to zoom on bodies without revealing faces. Hence, neither 
monitors nor confessors can accuse her of heresy as long as she posts videos regularly, albeit in poor quality. Along with Sandra, there is Cassius, who believes in science, calling for a rational society. Cassius belongs to the "Humanists" or "the vaccinators" - a group calls for kids' vaccination against the measles epidemic. For the Temple, vaccination is witchcraft and against God's will; hence, the vaccinator is guilty. Trafford, though, decides to vaccinate his daughter. Due to vaccine, Caitlin is the only kid who survive among all the children that used to live in her building. From Chantorria's perspective, vaccination, even valid, cannot be approved. Furthermore, it is only God's Mercy that protects Caitlin, not the vaccine. Nevertheless, whether the survival of Caitlin is because of science's capability or spiritual miracle, Trafford's and chantorria's beliefs were unfruitful because Caitlin dies because of cholera eventually. To this effect, Chantorria reports Trafford to the Temple's authority, blaming his heresy for the death of their daughter. Absurdly, despite Trafford's embrace of privacy, he chooses to share secrets with Sandra Dee who is an undercover government employee. Trafford's irrational act contributes in exposing the Humanists and their plans. Dee, in turn, enables the authorities to detain Trafford, Cassius, and all the privacy believers. At the day of "the great show" or "death by burning", Trafford confesses that he is a privacy believer. Thus, The Temple announces that he is a disbeliever who deserves execution. After all, it is Trafford's choice to share, rather than to keep secrets, which leads to his death.

\section{The Inundation of Choice: A Game of Twofold Threats}

Blind Faith, in many ways, symbolizes a closeended game with an - in advance - known outcome and 
proclaimed losers. As there are many defects in people's ability to choose rationality due to the flood disaster, 'blind following' becomes the new norm. In the novel, the society/individual game is one sided because individuals do not lift a finger to choose. In other words, they decide not to decide, hence announcing the Temple an everlasting winner.

According to the game-theoretic form, rationality is indispensable if the players aspire to achieve a profit. Therefore, narrowing the features of rational choices for any player, whether by threat or distraction, resembles nothing but this player's doom. In the novel, Elton announces an undeniable truth that we deal with a behaviorally unstable community. Besides the flood, the epidemic measles agitates the population by sending their beloved children to an early grave. Infection, in turn, unmercifully destroys the people's rational capacity. Trafford explains, "So many dead children ... Child mortality was the burning cross that burdened the souls of the nation, the pain the people must bear in repentance for the sins of their faithless forefathers" (14). By phasing in the threats, climatic, clinical, and finally ideological, Elton confirms the trouncing of his characters in the game. Yet, among the threats, it is blind faith, which utterly hampers the choices of people. In social games, belief always stands as a critical factor regarding people's preferences. After the flood, albeit enforced, people are still free to choose what happens next. However, the government decides to call for a suspicious gathering, represented in The Temple, proposing a new catalogue for faith. This blind faith obliges people to throw away their privacy and share online their lives, which resembles the recognition of guilt. 
Confessor Bailey claims, "Privacy .... is a blasphemy ... Only perverts do things in private. When we share our suffering we learn and we grow and we share our connection with God" (31). In light of this announcement, the game becomes fully-fledged as there are two players: the government versus people and two options: follow or resist. In this game, information is incomplete, as people do not understand why they should replace their old faith with 'excessive sharing'. In addition, the measles epidemic resembles a powerful threat, which affects people, using their irrational judgment after the flood. As human privacy is not negotiable, the solution of this game requires people to choose resistance. People, though, choose to follow the Temple's irrational rules, recording the first cooperative game in the novel.

So far, the government's behaviour regarding recommending such illogical rules stems from its inefficiency in crisis management. In the face of sequential disasters, distracting people appears a safe alternative to pick and choose. 'Online sharing' indeed helped the government's strategy. The new faith also, albeit blind, successfully soothed the fury of people. Therefore, after the flood, "the principal activity of the government was finding people something to do" (18). According to cooperative games, people/government's alliance is supposed to achieve a maximum profit for all the players under the condition of rationality. In the novel, no rational order is traced regarding the community's choices in general. Thus, despite cooperation, the outcome is not of high utility for both people and the government. Moreover, winning is transient as neither the government nor people gain control as expected. Mainly, the government hammers out its deal 
in the light of the belief that people are supposed to comply. At first, people's embrace of the Temple's rules aids the government's control strategy. Then, the crowds bludgeon the government into bearing the consequences of the new faith. As 'online sharing' reaches its limit, people's production capacity collapses - a fact that terrifies the government. Trafford explains how people become chaotic and slow after declaring the new faith, "No matter how much tidal planning the authorities imposed upon the commuting population, there was always a crowd at the entrance" (21). He adds, "People spent so much of their lives shuffling forward at a snail's pace that it had become part of the physical characteristics of the population" (21). Gradually, people become out of control to the extent that they disobey the governmental precautions that their faithful leaders set in the first place. Trafford mentions, 'The authorities often ran public heath campaigns urging people to straighten their backs and to take proper strides instead of pigeon steps" (21-22). However, "Nobody takes any notice" (22).

Throughout the novel, the cooperation of people and the government stands sturdily regardless of defection. In a sense, as the game continues, players are expected to distrust alliance after the loss, developing at least a stag hunt game instead of the latter cooperative one, especially if the information is not available for both parties. To our knowledge, 'the Temple' passes the rules of 'online sharing' to the whole country including its faithful leaders, then, why the reader cannot trace any data about the Temple's leaders in the novel. It looks like that the Temple exempts its leaders from 'sharing', and it seems like the community realizes that act. Trafford mentions, "faith leaders scanned 
their congregation's videos and no individual, no matter how anonyms, could afford to deny the community access to significant digital documentation of their lives" (115). According to game theory's standards, complete information is essential for the play order; therefore, under the lack of information, people are supposed to rejuvenate their strategy, hence ensuring their profit. In addition, the player can choose his interest rather than cooperation. In the case of Blind Faith, people firstly contribute in the game as players who choose among alternatives. After that, they absorb the new faith - declaring it an identity. Thus, no matter how the game echoes, the trust dilemma - which governs the social games - cannot exist because 'sharing' converts from being just an alternative into an unnegotiable belief.

Trafford, despite being a participant in the former game, doubts the rules of the Temple. He completely understands the circumstances of the new faith, but he finds the theory of 'sharing' preposterous. Here, the game changes when Trafford begins to move strategically by collecting information about the new faith, choosing privacy instead of 'sharing'. His decision depends on many facts that the community denies: firstly, although the NatDat bank monitors every blog, there is no thorough audit of the community's information as "To the best of Trafford knowledge, nobody ever looked at any of the information he sorted" and "He had never been called upon to supply any of it to anyone" (19). Secondly, if sharing is a necessity to clear the world from pedophilic, terrorists and disbelievers, then why "terrorism continued unabated anyway", despite the fact that terrorists already share their plans online. Thirdly, it is obvious that the Temple 
obliterates the era before flood where real faith existed, tampering with the laws for its benefit as privacy "had not always been a crime" even within the emergence of the new faith. Due to this reasonable calculation and in contrast to the old cooperative game, which bothers less, Trafford, begins a stag-hunt game. The game revolves around Trafford's declaration of his choice to the community, risking his safety for the sake of enlightening the community. For Trafford and any player, trust is the motivator of stage-hunt games, and predicting the moves of other players secures winning indeed. Hence, before declaration, Trafford outlines the alternatives of his decision as follows: Will society cooperate? Will the population easily get rid of 'online sharing'? Will the Temple consider the rational awakening of Trafford? What are the win-lose consequences? Will Trafford's choice attain his desired profit? He even begins the game with his wife - who is a community representative - before facing the community's disagreement. Chantorria unfortunately rejects Trafford's embrace of privacy, criticizing, "You and your stupid secrets. Why do you have to be so weird! Why do you have things to yourself? What's the point of it? Where does it get you?" (97). Realizing how blinded his wife so do the community, Trafford decides to keep his choice of privacy a secret. In this game, we consider Trafford a winner as he achieves two pay-offs: safety and privacy.

Since Trafford proceeds to keep up his privacy, he works towards enhancing his choice with optimal alliances. At this stage, the game calls for a new expected utility. Thus, Cassius who is a privacy believer offers cooperation to Trafford. Like prisoner's dilemma game, the 
confrontation between Trafford and Cassius is a two players' game with incomplete information. In this game, Trafford's options are: a) staying silent about his belief, b) averting suspicion by reporting Cassius to the officers, and c) performing an alliance. Although cooperation has the upper hand in this game, non-cooperation remains the perfect strategy because it maximizes Trafford's benefit. Therefore, Trafford firstly hesitates, denouncing Cassius's blasphemy. Yet, at the end Trafford chooses to cooperate as Cassius reveals his belief in privacy. Cassius mentions, "You are not the only one. I have secrets too. I have a very special one" (62). So far, both Trafford and Cassius were able to achieve mutual profit game until Sandra Dee's decisions, interfere with the game. By being a woman, Sandra Dee automatically passes the trust scan, which is an essential factor in cooperative games. Traditionally and socially, women are recognized as safe players who lack the capacity of bluffing and the language of rational complexity. Hence, depending on his information, which is complete from the social perspective, yet, imperfect in the game-theoretic application, Trafford does not begin a game of prisoner's dilemma with Sandra, unlike Cassius. Boldly, Sandra places herself into the category of privacy believers by sharing fake videos in her blog. Thus, neither Trafford nor Cassius suspects her. Excellent at manipulation, Sandra Dee fools the privacy believers from the beginning of the game. The fact that she posts fake data, and then she captures Trafford's attention as a privacy believer, confirms how strategically she plays. Thus, Sandra is considered as the most rational and acknowledgeable player in the novel. While the other players know nothing about her, she uses their online information to limit their moves. Furthermore, 
she takes advantage of her gender to distract other players. In the end, by uncovering all the privacy believers, she obtains a utility - which is the core of the game theory.

\section{Preference: The Social Right of Communities}

In Blind Faith, it is only social preferences that set the rules of playing in choice conflicts through controlling the moves of players, and enforcing credible and noncredible threats. According to game theory, any act of rationality that achieves a profit is welcomed regardless of its social background. On the other side, players should defy social law when it impedes utility.

In the novel, it is astonishing that people do not end the cooperative game with 'the Temple' despite being losers. Taking the Temple's authority in mind, it is understandable that people choose to cooperate under the pressure of surveillance, as Trafford puts it, "every click on every computer, every filling in every tooth was captured and entombed in the mainframes of NatDat" (19). However, Trafford clarified that the Temple's job relies upon collecting data rather than reviewing. Thus, if people post old contents or they do not post, it is the people's choice after all. Thaler's postulate of bounded rationality figures out why the population of the Temple prefers loss instead of wining after the flood. $\mathrm{He}$ summarizes the dilemma, "People will be risk-averse for gains, but riskseeking for loses" (33). In other words, people already lost their will because of the flood. Thus, they are ready to "take the risk of losing more in order to have the chance of getting back to no loss at all" (Thaler 33-34).

Apart from loss, the novel's characters are able to see the trouble in embracing the new faith not in a way every game theorist will, but much as any human will. Yet, 
"Choices are said to reveal preferences" and precisely social preferences. Thus in violating the social order, albeit irrational, people must be punished, but, why people preferred 'sharing' as a social necessity in the first place? Thaler and Sunstein respond, "Social influence come in two basic categories. The first involves information ... The second involves peer pressure" (58). In the world of blind faith, the available information about the era before the flood has been withheld except for some feigned data. Everybody believes that "The past was a place of ignorance, heresy and dark, dark sorcery" (26). Therefore, the individual may doubt the new faith but often het cannot get proofs or clues to quit. Shifting to the next element, Thaler and Sunstein think that "If" people "care about what other people think", they "might go along with the crowd to avoid their wrath" (58-59). Mainly, in the game, the community has the power to override people's decision. Therefore, those who do not voluntarily participate in the social dogma deserve elimination. That is what exactly happens in the novel, that, the social dogma obliges men to share their excitement and women to appear lustrous in their online broadcasting. Trafford illustrates, "The social pressure to be an obsessively sexual being was allencompassing. Every advert, every song, every reality show seemed to be about almost nothing but sex" (179). This choice resembles nothing but another insulting option to gain the acceptance of crowds, yet Thaler and Sunstein expect that "the incidence of undesirable behavior is high" especially when "people follow on another" (72). The matter expands to include Chantorria's panic when she recognizes the possibility of rescuing her daughter from the epidemic measles, because for the community 
'Immunization, be it of a child or an adult, was selfevidently an effort to restrict God's options, to cheat God, and it was therefore unarguably blasphemous" (65). Eventually, the survival of Chantorria's daughter and the community's children subjects to the social acceptance rather than a calculative sum of life/death probabilities.

\section{Conclusion}

This paper attempted to approach a qualified paradigm about choice games and social dilemmas by applying game theory and Thaler's contributions about decision-making on Cloud Atlas and Blind Faith. Generally, the characters of both novels testified their decisions under actual/fabricated threats in the society/individual games where information varied between perfection and fragmentation, providing extra pressure to the players. Mainly, the characters were warned about the consequences of their decisions in each game. No remarkable change, yet, was traced in the characters' moves to adapt to the variables of time or culture. As choice is a manifestation of the game-theoretic rationality, the study believes that all the characters are irrational forasmuch they achieve. Even after their confirmed loss, none of the characters adopted a different strategy that guaranteed a profit.

In both novels, decision-making, the characters' battlefield, was severely affected by the social influence. There was no mathematical or moral explanation related to the characters' behaviours except that the social preferences determined the rules of the game in advance. By offering safe and proved choices, without having coerce to play in the first place, social preferences subverted the rational and the human considerations of characters. What they chose, 
how they decided, when they should cooperate, and whom they trusted - were all contingent on the social contract. Thus, even with facing disadvantages of dogmatic deviation, irrational calculation, and risk probability, characters chose to follow the rules of society.

While most of the characters misplayed, few somehow obtained a strategy to switch the game on their behalf. They, however, could not afford resilience while playing against social preferences no matter how the solution of the game was accessible. Their choices, albeit right, stimulated a rehash of the vacuous defected decisions, therefore, once breaking the rules of society and winning the game partially, the characters' rationality attenuated by the social pressure again, achieving a fatal loss. Therefore, although the novels' incidents moved forward, presenting new games and new conditions, the players brought out the same outcome repeatedly, making choices purposeless. 


\section{Works Cited}

Axelrod, Robert. "Effective Choice in the Prisoner's Dilemma." The Journal of Conflict Resolution, vol. 24, no. 1, 1980, pp. 325. JSTOR, www.jstor.org/stable/173932. Accessed 3 April 2021.

Baddeley, Michelle. Behavioural Economics: A Very Short Introduction. Oxford UP, 2017.

"Behavioral Economics." Encyclopedia of Social Psychology, edited by Roy F. Baumeister and Kathleen D. Vohs, vol. 1, Sage Publications, 2007, pp. 103-108.

Bolton, Gary E., et al. "Social Interaction promotes Risk Taking in a Stag Hunt Game." German Economic Review, vol. 17, no. 3, 11 May 2016, pp. 409-423. Wiley, onlinelibrary.wiley.com/doi/full/10.1111/geer.12095. Accessed 3 Dec. 2019.

Brams, Steven J. Game Theory and the Humanities: Bridging Two Worlds. The MIT P, 2011.

Davis, Morton D. Game Theory: A Nontechnical Introduction. Dover publications, 1997.

Duignan, Brian. "Richard Thaler." Encyclopedia Britannica, 8 Sep. 2020, www.britannica.com/biography/Richard-Thaler. Accessed 15 Dec. 2020.

Elton, Ben. Blind Faith. Black Swan, 2007.

Fang, Christina, et al. "On Adaptive Emergence of Trust Behavior in the Game of Stag Hunt." Group Decision and Negotiation, vol. 11, 2002, pp. 449-467. Springer, doi: 10.1023/A:1020639132471.

Gibbons, Robert. "An Introduction to Applicable Game Theory." The Journal of Economic Perspectives, vol. 11, no. 1, 1997, pp. 127149. JSTOR, www.jstor.org/stable/2138255. Accessed 6 July 2019.

Lisciandra, Chiara. "The Role of Psychology in Behavioral Economics: The Case of Social Preferences." Studies in History and Philosophy of Science Part A, vol. 72, 2018, pp. 1121. Elsevier, doi:10.1016/j.shpsa.2018.01.010. 
Mezey, Jason Howard. '"A Multitude of Drops': Recursion and Globlization in David Mitchell's Cloud Atlas."Modern Language Studies, vol. 40, no. 2, 2011, pp. 10-37. JSTOR, www.jstor.org/stable/23339629. Accessed 19 July 2019.

Mitchell, David. Cloud Atlas. New York: Random House Trade Paperbacks, 2004.

Morrow, James D. Game Theory for Political Scientists. Princeton UP, 1994.

Mullainathan, Sendhil, and Richard Thaler. "Behavioral Economics." 2000. National Bureau of Economic Research. NBER, doi: 10.3386/w7948.

Myerson, Roger B. Game Theory: Analysis of Conflict. Harvard UP, 1997.

Narveson, Jan. "The Relevance of Decision Theory to Ethical Theory." Ethical Theory and Moral Practice, vol. 13, no. 5, Nov. 2010, pp. 497-520.

Springer, link.springer.com/article/10.1007/s10677-009-9193-3.

Nash, John F. Non-Cooperative Games. 1950. Princeton U, PhD dissertation. Scribd, www.scribd.com/doc/4800022/John-Nashs-Ph-D-Thesis.

Ng, Lynda. "Cannibalism, Colonialism and Apocalypse in Mitchell's Global Future." SubStance, vol. 44, no. 1, 2015, pp. 107-122. JSTOR, www.jstor.org/stable/24540792. Accessed 3 May 2019.

Romp, Graham. Game Theory: Introduction and Applications. Oxford UP, 1997.

Siegfried, Tom A Beautiful Math: John Nash, Game Theory and the Modern Quest for a Core of Nature. Joseph Henry Press, 2006.

Skyrms, Brian. The Stag hunt and the Evolution of Social Structure. Cambridge UP, 2004.

Thaler, Richard H. Misbehaving: The Making of Behavioral Economics. Penguin Books, 2016.

Thaler, Richard H., and Cass R. Sunstein. Nudge: Improving Decisions about Health, Wealth and Happiness. Penguin Books, 2009. 
Walther, Andre. The Apocalypse in our Heads: The World as "the Mind's Mirror" in Mitchell's Cloud Atlas. 2017. Clark U, MA thesis. ProQuest, www.proquest.com/dissertationstheses/apocalypse-our-heads-world-as-mindsmirror/docview/1964384624/se-2 ?accountid=178282. 